\title{
KARAKTERISASI KULIT KAMBING PADA PERSIAPAN PENYAMAKAN DENGAN GAMBIR DAN SIFAT KULIT TERSAMAK YANG DIHASILKAN
}

\section{CHARACTERIZATION OF GOAT SKIN ON PREPARATION OF LEATHER TANNED WITH GAMBIER AND PROPERTIES OF LEATHER}

\author{
Anwar Kasim, Deni Novia, Sri Mutiar, Janwaris Pinem \\ Agricultural Technology, Andalas University, Padang \\ Email: anwarks@yahoo.com \\ Diterima: 7 Januari 2013 Direvisi: 11 Maret 2013 Disetujui: 4 April 2013
}

\begin{abstract}
The purposes of this research were to evaluate characteristic of goat skin before preparation for tanning, to observe the effect of concentration of gambier tanning agent and $\mathrm{pH}$ of gambier solution during tanning process. This research began with characterizing of skin before the tanning process. Gambier concentrations and $p H$ of solutions were varied. Characterization of the goat skin was done on the area of goat skin, chemical composition, and weight change at each steps of tanning preparations. Physical and chemical analysis and observation of the leather were done according to SNI-06-0463-1989-A. Goat skin in this research was categorized as first quality according to the wide dimension and high water content. The results showed that the characteristics of dried goat skins changed during preparation and tanning process. The optimum concentration of gambier was $9 \%$ if the solution had a pH of 4 and the optimum concentration was 3\% if the solution had a pHof 8 .
\end{abstract}

Keywords: goat skin, tanning, gambier, concentration, $p H$

\begin{abstract}
ABSTRAK
Tujuan penelitian ini adalah untuk mengetahui karakteristik kulit kambing pada persiapan penyamakan, melihat pengaruh perbedaan konsentrasi bahan penyamak gambir dan pH larutan penyamak gambir selama proses penyamakan. Pelaksanaan penelitian dimulai dengan karakterisasi kulit sebelum proses penyamakan kemudian dilanjutkan penyamakan menggunakan gambir. Konsentrasi gambir pada penyamakan ada 5 tingkat yaitu $A 1=3 \%$, $\mathrm{A} 2=6 \%, \mathrm{~A} 3=9 \%, \mathrm{~A} 4=12 \%$ dan $\mathrm{A} 5=15 \%$ adapun $\mathrm{pH}$ larutan 2 tingkat yaitu $\mathrm{pH} 4$ dan $\mathrm{pH} 8$. Bahan baku yang digunakan dalam penelitian ini adalah kulit kambing kering awet garam. Karakterisasi dilakukan terhadap luas kulit kambing, komposisi kimia, dan perubahan berat kulit pada setiap langkah persiapan penyamakan. Analisis kimia dan pengamatan sifat kulit dilakukan terhadap kulit tersamak dengan mengacu kepada SNI-06-0463-1989-A. Kulit kambing penelitian adalah termasuk kualitas I berdasarkan dimensi luas dengan kadar air yang relatif tinggi. Ada penambahan dan penurunan berat kulit selama proses pembuatan pikel dan penyamakan kulit. Rendemen pengolahan adalah $32,91 \%$ sampai $43,53 \%$. Konsentrasi optimum zat penyamak gambir adalah 9\% jika larutannya mempunyai $\mathrm{pH} 4$ dan konsentrasi optimum 3\% jika larutannya mempunyai $\mathrm{pH} 8$. Sifat kulit tersamak jika konsentrasi gambir $9 \%$ dan larutan mempunyai $\mathrm{pH} 4$ adalah kadar zat kulit mentah 50,14\%, kadar tanin terikat $13,47 \%$, derajat penyamakan $26,86 \%$, kekuatan tarik $418,48 \mathrm{~kg} / \mathrm{cm}^{2}$ dan kemuluran pada waktu putus $54,80 \%$, sedangkan jika konsentrasi gambir 3\% dan larutan mempunyai $\mathrm{pH} 8$ adalah kadar zat kulit mentah 50,91\%, kadar tanin terikat $13,17 \%$, derajat penyamakan $27,51 \%$, kekuatan tarik $427,94 \mathrm{~kg} / \mathrm{cm}^{2}$ dan kemuluran pada waktu putus $45,87 \%$.
\end{abstract}

Kata kunci: kulit kambing, penyamakan, gambir, konsentrasi, $\mathrm{pH}$ 


\section{PENDAHULUAN}

Ketersediaan bahan baku kulit kambing sebagai bahan dasar penyamakan kulit peningkatannya sejalan dengan program pembangunan peternakan di Sumatera Barat. Peningkatan populasi ternak kambing tersebar diseluruh daerah ini. Berdasarkan data Direktorat Jenderal Peternakan (2011) populasi kambing di Provinsi Sumatera Barat tahun 2007 tercatat 221.276 ekor, tahun 2008 sebanyak 227.561 ekor, tahun 2009 sebanyak 232.647 ekor dan 2010 sebanyak 262.140 ekor. Jenis kambing yang banyak dikembangkan adalah dari jenis peranakan Ettawa yang memiliki banyak keunggulan dibandingkan dengan kambing kampung (Kambing Kacang). Kambing Ettawa memiliki tubuh yang relatif lebih besar dan dapat dijadikan sebagai kambing pedaging dan kambing perah. Kulit dari jenis kambing Ettawa memiliki ukuran yang lebih luas sehingga yang sangat baik dimanfaatkan sebagai bahan baku penyamakan kulit.

Menurut Ibrahim et al. (2005), kulit kambing merupakan salah satu hasil samping dari pemotongan hewan yang ada di Rumah Pemotongan Hewan (RPH) dan yang bukan di RPH. Ketersediaan kulit kambing sebagai hasil samping masih sangat terbatas dan lokasi penyamakan kulit tidak selalu berdekatan dengan tempat pemotongan hewan, hal ini menyebabkan industri harus menumpuk kulit mentah. Kulit mentah ini mudah mengalami kerusakan oleh mikroorganisme sehingga perlu dilakukan proses pengawetan seperti pemberian garam dan pengeringan. Kulit mentah awet kering dapat disimpan sampai waktu tertentu sesuai dengan kapasitas penyamakan pada industri.

Penyamak nabati merupakan bahan penyamak non mineral yang dihasilkan dari sumber daya alam seperti mimosa, quebracho dan gambir. Mimosa dihasilkan dari kayu dan kulit kayu Acacia mearnsii, quebracho dari kayu Schinopsis lorentzii dan gambir dari daun dan ranting tanaman Uncaria gambier. Kulit yang disamak dengan penyamak nabati umumnya berwarna coklat muda atau kemerahan sesuai dengan warna bahan penyamaknya (Kasim, 2011). Di Sumatera Barat pada umumnya industri rumah tangga penyamakan kulit menggunakan bahan babakan kayu akasia yang dikenal dengan mimosa. Begitu juga pada Unit Pelaksanaan Teknis Daerah penyamakan kulit kota Padang Panjang, juga menggunakan mimosa sebagai bahan retanning pada penyamakan kombinasi (UPTD Padang panjang, 2011). Mimosa adalah barang impor, oleh sebab itu perlu dicari alternatif pengganti mimosa, salah satunya yang paling tepat adalah gambir. Laporan hasil penelitian di wilayah Mesir oleh Nasr et al. (2013) menyatakan bahwa bahan penyamak nabati quebracho lebih baik dari mimosa, dimana penggunaan mimosa menyebabkan kulit lebih tipis, menyerap air dan meningkatkan kekuatan tarik, dengan demikian penelitian ini penggunaan mimosa sebagai bahan penyamak nabati tidak disarankan.

Gambir (Uncaria gambir) adalah tanaman asli Asia Tenggara, khususnya Indonesia dan Malaysia. Tanaman ini telah banyak digunakan sebagai bahan obat-obatan, penyamakan kulit, tinta dan zat warna. Gambir sebagian besar terdiri dari monomer flavanol seperti catechin, epicatechin dan alkaloid (Achmad et al., 2012). Menurut Markmann (2009) gambir dikategorikan kepada jenis ekstrak yang spesial untuk penyamakan kulit. Senyawa tanin yang terdapat di dalam gambir menyatu secara cepat dengan protein kulit untuk memproduksi hasil samakan yang cocok sebagai bahan dasar ikat pinggang dan tas, terutama yang dikerjakan dengan tangan.

Gambir sangat berpeluang menggantikan mimosa. Hal ini didukung oleh ketersediaan gambir yang merupakan produk hasil pertanian penting di Sumatera Barat. Data BPS Provinsi Sumatera Barat (2009), menyebutkan luas tanaman gambir di Sumatera Barat lebih kurang $19.575 \mathrm{Ha}$ dengan total produksi 13.956 ton dimana $80 \%$ pasar ekspor komoditi gambir dunia berasal dari Indonesia dan 80\% ekspor gambir dari Indonesia dipasok oleh Provinsi Sumatera Barat.

Berdasarkan hasil survei lapangan tentang penggunaan bahan penyamak nabati pada industri rumah tangga adalah dalam bentuk babakan kayu akasia yang dihaluskan kemudian direndam dengan air dengan perbandingan 1:4 dan pada UPTD penyamakan kulit kota Padang Panjang 
penggunaan mimosa dalam bentuk bubuk mimosa impor adalah $10 \%$ yang dihitung terhadap berat pikel. Informasi tentang penggunaan konsentrasi gambir sebagai penyamak nabati tidak banyak tersedia apalagi dikaitkan dengan $\mathrm{pH}$ larutan gambir saat dilakukan penyamakan kulit.

Selain konsentrasi bahan penyamak, proses penyamakan juga dipengaruhi oleh $\mathrm{pH}$ larutan. Menurut Purnomo (1991) dalam penyamakan nabati $\mathrm{pH}$ larutan bahan penyamaknya harus diatur. Pada awal proses penyamakan $\mathrm{pH}$ larutan setelah ditambahkan bahan harus diatur agar bahan penyamak mudah masuk kedalam jaringan serat kulit. Bahan penyamak akan masuk sempurna kedalam kulit apabila bahan penyamak tersebut larut dengan baik dalam air pada proses penyamakan. Ditambahkan oleh Haron et al. (2012) bahwa terdapat beberapa faktor yang mempengaruhi penyamakan kulit seperti basisitas, konsentrasi, temperatur, waktu proses penyamakan dan nilai $\mathrm{pH}$.

Gambir merupakan salah satu bahan penyamak yang mempunyai kelarutan yang baik dalam air. Kelarutan gambir dalam air dipengaruhi oleh $\mathrm{pH}$ larutan. Menurut Kasim (2011) pH kelarutan gambir yang baik adalah 8-10.

Berdasarkan uraian diatas, maka dilakukan penelitian penggunaan gambir sebagai bahan penyamak nabati yang banyak tersedia di dalam negeri khususnya Sumatera Barat untuk menghasilkan kulit samak dengan stabilitas tinggi dan memenuhi standar industri. Lebih lanjut diharapkan terbukanya peluang pemanfaatan gambir dalam negeri sebagai penyamak kulit. Disamping itu juga diamati karakteristik kulit pada persiapan penyamakan dan pada proses penyamakan.

\section{BAHAN DAN METODE Bahan Penelitian}

Bahan dan zat kimia yang dibutuhkan dalam penelitian ini adalah gambir, tawas, kulit kambing ettawa, kapur, natrium sulfida, aquadest, asam sulfat, natrium karbonat, natrium bikarbonat, amonium sulfat, asam formiat, teepol, oropon, preventol, natrium formiat, garam dapur, heksana, kertas saring, selenium mix, natrium hidroksida dan indikator MMB.

\section{Peralatan Penelitian}

Peralatan yang digunakan yaitu shaker, desikator, cawan porselin, oven listrik, tanur, labu ukur, erlenmeyer, timbangan analitik, batang pengaduk, gelas ukur, corong, penangas air, drum berputar dan labu kjeldahl.

\section{Metode Penelitian}

Penelitian dimulai dengan pengumpulan sampel kulit kambing kering. Pengamatan karakteristik kulit kambing dilakukan dengan pengukuran dan penimbangan beberapa kulit secara sampling. Selanjutnya dilakukan pembuatan pikel, penyamakan dan pengeringan kulit. Kulit hasil samak digunakan untuk analisis kimia dan pengamatan sifat fisik.

Penyamakan kulit dilakukan dengan menggunakan gambir pada beberapa tingkat konsentrasi gambir yaitu $\mathrm{A} 1=3 \%, \mathrm{~A} 2=6 \%$, $\mathrm{A} 3=9 \%, \mathrm{~A} 4=12 \%$, dan $\mathrm{A} 5=15 \%$. Tiap tingkat konsentrasi dilakukan pada 2 kondisi keasaman yaitu $\mathrm{pH} 4$ dan $\mathrm{pH} 8$.

Prosedur kerja penyamakan kombinasi menggunakan drum berputar, berdasarkan modifikasi metode BBKKP (2011) adalah sebagai berikut: Pengerjaan basah yang terdiri dari: perendaman kulit kering, pengapuran, penimbangan bloten, buang kapur, pengikisan protein dan pengasaman kulit. Kulit disamak dalam drum berputar. Pikel disamak dengan 5 tingkat konsentrasi dan 2 tingkat tingkat keasaman larutan gambir. Kulit setelah pengasaman disamak dalam larutan gambir pada berbagai level konsentrasi gambir sesuai dengan perlakuan $\mathrm{A} 1=3 \%, \mathrm{~A} 2=6 \%, \mathrm{~A} 3=9 \%$, $\mathrm{A} 4=12 \%, \mathrm{~A} 5=15 \%$, masing-masing perlakuan diatur larutan gambir pada $\mathrm{pH} 4$ dan $\mathrm{pH} 8$. Drum penyamakan diputar selama 60 menit dan kemudian dilakukan overnight. pencucian dengan air mengalir untuk menghilangkan sisa zat penyamak yang masih melekat, kemudian dilakukan pengeringan dengan cara pementangan.

\section{HASIL DAN PEMBAHASAN}

Karakteristik Kulit Kambing Mentah

1. Berat dan luas kulit kambing mentah

Hasil pengamatan karakteristik kulit kambing mentah dilakukan terhadap 10 sampel kulit yang diambil secara acak seperti lengkapnya dijelaskan pada 
Tabel 1. Rata-rata berat dan luas kulit kambing Ettawa asal Sumatera Barat

\begin{tabular}{lllcc}
\hline No & Parameter yang diamati & Satuan & Rata-rata & Kisaran \\
\hline 1 & Luas sampel $(13 \mathrm{~cm} \times 23 \mathrm{~cm})$ & $\mathrm{cm}^{2}$ & 299 & \\
2 & Berat untuk tiap 299 $\mathrm{cm}^{2}$ & gram & 45,70 & $27,86-67,03$ \\
3 & Berat tiap 1 cm & gram & 0,14 & $0,09-0,22$ \\
4 & Berat kulit utuh & gram & 1005,16 & $487,03-1783,54$ \\
5 & Luas kulit utuh & $\mathrm{cm}^{2} *$ & 6945,62 & $3463-16896$ \\
6 & Panjang & $\mathrm{cm}$ & 101,88 & $73,55-119,38$ \\
7 & Lebar & $\mathrm{cm}$ & 81,51 & $58,84-95,51$ \\
\hline
\end{tabular}

*Hasil bagi antara berat kulit utuh dengan berat tiap $\mathrm{cm}^{2}$

metodologi. Angka hasil pengamatan kemudian dirata-ratakan. Pada Tabel 1 dicantumkan hasil pengamatan dan perhitungan kulit kambing yang digunakan pada penelitian.

Dari hasil pengamatan terhadap lebar rata-rata kulit didapatkan $81,51 \mathrm{~cm}$ dan panjang rata-rata $101,88 \mathrm{~cm}$ sehingga rata-rata luas kulit utuh adalah $6945,62 \mathrm{~cm}^{2}$. Suardana, et al. (2008) menyatakan kulit kambing tidak ditentukan berdasarkan beratnya, tetapi berdasarkan panjang tengah-tengah dari ekor hingga leher dan lebar kulitnya. Pembagian kualitas kulit kambing dapat dibedakan menjadi: (1) kelas I: kulit yang panjangnya $100 \mathrm{~cm}$ dan lebarnya $70 \mathrm{~cm}$, (2) kelas II: kulit yang panjangnya $100 \mathrm{~cm}$ dan lebarnya $60 \mathrm{~cm}$, (3) kelas III : kulit yang panjangnya $90 \mathrm{~cm}$ dan lebarnya $55 \mathrm{~cm}$, (4) kelas IV : kulit yang panjangnya $80 \mathrm{~cm}$ dan lebarnya $50 \mathrm{~cm}$, (5) kelas V: kulit yang panjangnya $70 \mathrm{~cm}$ dan lebarnya $45 \mathrm{~cm}$ dan (6) kelas afkir dimana panjang kulit kurang dari $70 \mathrm{~cm}$. Berdasarkan pengelompokkan tersebut kulit kambing yang digunakan dalam penelitian ini termasuk kedalam kelas I dengan panjang kulit rata-rata $101,88 \mathrm{~cm}$ dan lebar rata-rata $81,51 \mathrm{~cm}$.

\section{Hasil analisis kimia kulit kambing mentah}

Berdasarkan hasil analisis kulit kambing mentah awet kering didapat kadar air kulit $27,32 \%$, kadar lemak 0,37\%, kadar abu $2,17 \%$, kadar zat larut dalam air 0,24\% dan kadar protein 46,89\%. Menurut Purnomo dan Wazah (1984), sifat-sifat kimiawi dari kulit menentukan reaksi pada proses penyamakan seperti kondisi fisik dari serabut kulit.

\section{Perubahan berat kulit kambing selama pengerjaan basah}

Proses penyamakan kulit diawali dengan proses pengerjaan basah (beam house) seperti: perendaman (soaking), pengapuran (liming), pembelahan (splitting), pembuangan kapur (deliming), dan pengikisan protein (bating). Setiap proses pengerjaan kulit mengalami peningkatan dan penurunan berat akibat penggunaan bahan kimia yang terikat pada kulit serta kehilangan berat sebagai akibat dari degradasi komponen-komponen tertentu akibat proses pengerjaan. Adapun hasil pengamatan terhadap perubahan berat kulit pada pengerjaan basah dapat dilihat pada Tabel 2.

Tabel 2. Perubahan berat kulit selama proses pengerjaan basah

\begin{tabular}{llccc}
\hline No & Pengamatan & Berat $(\mathrm{g})$ & $\begin{array}{c}\text { Peningkatan } \\
\text { berat }(\%)\end{array}$ & $\begin{array}{c}\text { Penurunan } \\
\text { berat }(\%)\end{array}$ \\
\hline 1 & Kulit kering & 24,47 & - & - \\
2 & Kulit setelah perendaman & 52,32 & $215,13^{*}$ & - \\
3 & Bloten & 55,38 & $6,70^{* *}$ & - \\
4 & Pikel & 45,26 & $84,96^{*}$ & $16,28^{* * *}$ \\
\hline
\end{tabular}

*dihitung terhadap berat kulit kering

**dihitung terhadap berat rendaman

$* * *$ dihitung terhadap bloten 
Proses pengerjaan basah merupakan proses penyiapan kulit mentah sebelum proses penyamakan dilakukan mulai dari perendaman sampai pikel. Kulit kambing awet kering yang digunakan dalam penelitian ini dilakukan perendaman selama 24 jam yang bertujuan untuk mengembalikan kadar air dari kulit mentah. Selama proses perendaman berat kulit meningkat sebesar $121,86 \%$ yang dihitung berdasakan berat kering karena penyerapan air ke dalam kulit. Begitu juga dengan proses pembuangan bulu yang dihitung berdasarkan berat kulit setelah perendaman. Setelah proses perendaman dilanjutkan dengan pembuangan bulu untuk memperoleh bloten. Berat bloten juga mengalami peningkatan sebesar $6,70 \%$. Berat kulit setelah perendaman 52,32 g kemudian diperoleh berat bloten 55,38 g. Sebelum dilakukan proses pikel kulit mengalami beberapa proses seperti pembuangan lemak dan bating, sehingga berat kulit pada pikel mengalami penurunan sebesar 16,28\%.

\section{Karakteristik Kulit Kambing Hasil Penyamakan}

\section{Perubahan berat pikel pada proses penyamakan}

Hasil pengamatan karakteristik kulit dalam proses penyamakan pada larutan gambir pH4 dapat dilihat pada Tabel 3 .

Berdasarkan Tabel 3 dapat dilihat bahwa setelah proses penyamakan dengan bahan gambir pada konsentrasi 3\%, 6\%, 9\% dan $12 \%$ kulit mengalami peningkat berat. Hal ini disebabkan terjadinya ikatan antara bahan penyamak dengan protein kulit. Namun penggunaan konsentrasi yang lebih tinggi $15 \%$ menunjukkan terjadinya penurunan berat kulit sebesar 6,08\%. Hal ini disebabkan oleh penggunaan bahan penyamak nabati dengan konsentrasi yang tinggi menyebabkan daya penetrasinya kedalam kulit rendah. Hal ini sesuai dengan pendapat Purnomo (1991) bahwa zat penyamak nabati pada konsentrasi yang tinggi memiliki molekul yang lebih besar dibandingkan dengan konsentrasi rendah, daya samak tinggi namun penetrasi kedalam kulit rendah. Menurut Haron et al. (2012), tanin dalam proses penyamakan secara kimia beraksi dengan kulit membentuk ikatan crosslinks dengan kolagen kulit, grup tanin aktif berikatan dengan grup protein yang terdapat didalam kulit.

\section{Karakteristik kulit kering hasil penyamakan}

Karakteristik kulit tersamak meliputi rendemen, tebal kulit, densitas, pengamatan visual dari segi warna, kehalusan dan tingkat kelemasan kulit dapat dilihat pada Tabel 4.

Hasil penelitian menunjukkan bahwa rendemen kulit tersamak berkisar antara $32,91 \%$ sampai dengan $43,53 \%$ dengan penggunaan berbagai konsentrasi bahan penyamak gambir. Ketebalan kulit rata-rata $0,11 \mathrm{~mm}$ dengan densitas 0,63 sampai 0,76 $\mathrm{g} / \mathrm{cm}^{3}$. Jika dibandingan dengan penyamakan nabati berbahan oxazolidine kulit yang dihasilkan lebih tebal yaitu $1,5 \mathrm{~mm}$ (Roigl et al., 2012). Secara keseluruhan hasil penyamakan dengan gambir memberikan warna kuning, lembut, ringan, halus dan lemas. Hal ini sesuai dengan pendapat Kasim (2011) bahwa hasil penyamakan dengan gambir memberikan warna kuning menarik, lembut dan bila dipegang terasa ringan dan halus.

Tabel 3. Perubahan berat kulit selama proses penyamakan pada larutan gambir $\mathrm{pH} 4$

\begin{tabular}{ccccc}
\hline No & $\begin{array}{c}\text { Konsentrasi } \\
\text { gambir }(\%)\end{array}$ & $\begin{array}{c}\text { Berat pikel } \\
(\mathrm{g})\end{array}$ & $\begin{array}{c}\text { Peningkatan } \\
\text { berat }(\%)^{*}\end{array}$ & $\begin{array}{c}\text { Penurunan } \\
\text { berat }(\%)\end{array}$ \\
\hline 1 & 3 & 81,24 & 11,06 & - \\
2 & 6 & 74,82 & 10,31 & - \\
3 & 9 & 68,18 & 15,70 & - \\
4 & 12 & 64,78 & 14,23 & - \\
5 & 15 & 57,99 & - & 6,08 \\
\hline
\end{tabular}

*dihitung berdasarkan berat kulit basah setelah penyamakan 
Tabel 4. Rendemen, tebal kulit, densitas dan pengamatan visual kulit tersamak pada larutan gambir $\mathrm{pH} 4$

\begin{tabular}{ccccccc}
\hline $\begin{array}{c}\text { Konsentrasi } \\
\text { gambir }(\%)\end{array}$ & $\begin{array}{c}\text { Rendemen } \\
(\%)^{*}\end{array}$ & $\begin{array}{c}\text { Tebal } \\
\text { Kulit } \\
(\mathrm{cm})\end{array}$ & $\begin{array}{c}\text { Densitas } \\
\left(\mathrm{g} / \mathrm{cm}^{3}\right)\end{array}$ & Warna & Kehalusan & $\begin{array}{c}\text { Tingkat } \\
\text { kelemasan }\end{array}$ \\
\hline 3 & 38,15 & 0,11 & 0,63 & Pale yellow & Halus & Lemas \\
6 & 37,96 & 0,11 & 0,76 & Yellow & Halus & Lemas \\
9 & 36,29 & 0,12 & 0,76 & Light gray & Halus & Lemas \\
12 & 32,91 & 0,11 & 0,80 & Yellow & Halus & Lemas \\
15 & 43,53 & 0,11 & 0,63 & Yellow & Halus & Lemas \\
\hline
\end{tabular}

* dihitung terhadap berdasarkan berat kulit basah setelah perendaman

Tabel 5. Nilai rata-rata hasil analisis kimia kulit tersamak pada penggunaan gambir berbagai konsentrasi pada 2 level $\mathrm{pH}$.

\begin{tabular}{ccccccc}
\hline \multirow{2}{*}{$\begin{array}{c}\text { Konsentrasi } \\
\text { gambir (\%) }\end{array}$} & $\begin{array}{c}\text { Kadar zat kulit } \\
\text { mentah (\%) }\end{array}$ & $\begin{array}{c}\text { Kadar zat penyamak } \\
\text { terikat (\%) }\end{array}$ & \multicolumn{2}{c}{$\begin{array}{c}\text { Derajat } \\
\text { penyamakan (\%) }\end{array}$} \\
\cline { 2 - 7 } & $\mathrm{pH} \mathrm{4}$ & $\mathrm{pH} \mathrm{8}$ & $\mathrm{pH} \mathrm{4}$ & $\mathrm{pH} \mathrm{8}$ & $\mathrm{pH} \mathrm{4}$ & $\mathrm{pH} \mathrm{8}$ \\
\hline 3 & 52,75 & 50,91 & 4,32 & 13,17 & 8,72 & 27,51 \\
6 & 53,51 & 52,01 & 10,93 & 14,88 & 24,45 & 31,87 \\
9 & 50,14 & 42,64 & 13,47 & 16,21 & 26,87 & 35,56 \\
12 & 51,83 & 45,11 & 14,27 & 17,15 & 27,51 & 38,01 \\
15 & 50,38 & 48,02 & 15,50 & 18,26 & 29,86 & 38,02 \\
\hline \multicolumn{3}{l}{ SNI-06-0463-1989-A } & - & \multicolumn{4}{c}{ Minimal 25\% } \\
\hline
\end{tabular}

\section{Analisis kimia kulit tersamak}

Hasil analisis kimia kulit tersamak dari berbagai konsentrasi bahan penyamak gambir pada laruran gambir $\mathrm{pH} 4$ dan $\mathrm{pH} 8$ dapat dilihat pada Tabel 5 .

Hasil analisis kadar zat penyamak terikat dan derajat penyamakan kulit menunjukkan peningkatan pada larutan gambir $\mathrm{pH} 4$ dan $\mathrm{pH} 8$ dengan semakin tingginya konsentrasi gambir pada penyamakan. Rata-rata kadar zat kulit mentah kulit kambing yang disamak dengan gambir berkisar antara 50,14\% sampai 52,75\% pada kondisi $\mathrm{pH} 4$ dan pada kondisi pH 8 kadar zat kulit mentah berkisar 42,64\% sampai 50,91\%.

Zat kulit mentah hasil penyamakan menunjukkan hasil yang cenderung mengalami penurunan seiring dengan peningkatan konsentrasi gambir. Menurut Purnomo (1991) bila kolagen bereaksi dengan bahan penyamak kulit akan menjadi tahan terhadap kondisi asam dan basa serta mikroorganisme, dalam kata lain kondisi kulit menjadi stabil dibandingkan dengan kulit mentah.

Jumlah zat penyamak terikat (tanin terikat) pada kolagen kulit dipengaruhi oleh banyaknya tanin yang berdifusi kedalam jaringan kulit. Menurut Suparno et al. (2010) penyamakan dengan menggunakan bahan penyamak nabati akan membentuk crosslinking dengan kolagen kulit, ikatan hidrogen dan ikatan kovalen yang menghasilkan kulit samak. Ditambahkan oleh Brown et al. (2011) bahwa bahan penyamak nabati teridentifikasi membentuk ikatan hidrogen lebih banyak dengan molekul protein arginin dan interaksi hidrofobik dengan molekul arginin atau isoleusin.

Hubungan antara pengaruh berbagai konsentrasi bahan penyamak gambir dengan kadar zat penyamak terikat pada larutan gambir $\mathrm{pH} 4$ dan $\mathrm{pH} 8$ dapat dilihat pada Gambar 1. 


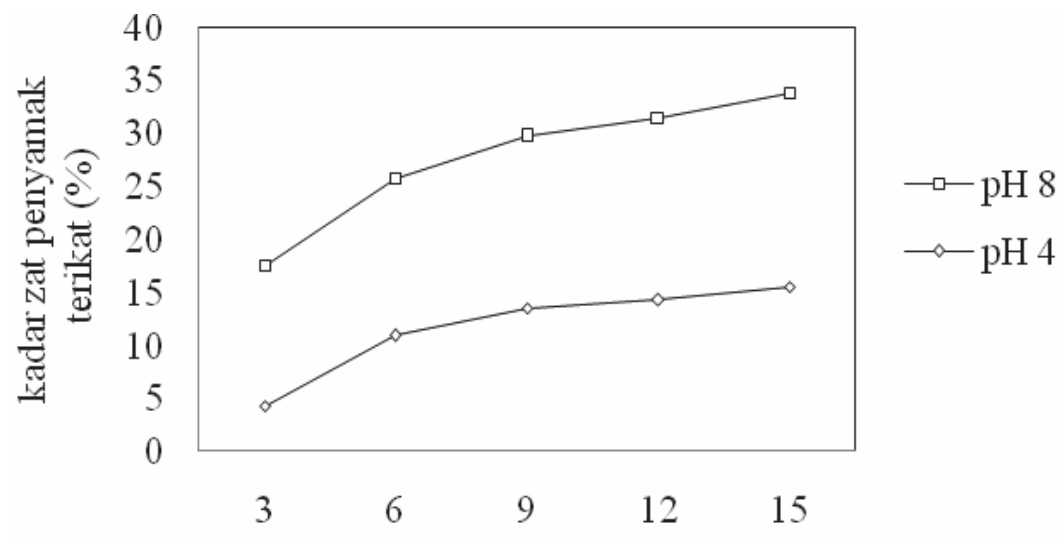

Konsentrasi gambir (\%)

Gambar 1. Hubungan antara konsentrasi bahan penyamak gambir dengan kadar zat penyamak terikat pada larutan gambir $\mathrm{pH} 4$ dan $\mathrm{pH} 8$.

Hasil penelitian menunjukkan semakin tinggi konsentrasi penggunaan gambir maka jumlah tanin terikat juga semakin meningkat. Jika dibandingkan antara kedua kondisi $\mathrm{pH}$ penyamakan, kondisi $\mathrm{pH} 8$ menunjukkan kadar zat penyamak yang lebih tinggi dibandingkan dengan kondisi $\mathrm{pH} 4$. Hal ini karena kelarutan gambir pada kondisi basa lebih baik. Menurut Kasim (2011), $\mathrm{pH}$ kelarutan gambir yang baik berkisar 8 sampai 10.

Hasil analisis kadar zat penyamak terikat kulit tersamak dengan menggunakan gambir dengan kondisi $\mathrm{pH} 4$ berkisar antara 4,32\% sampai $15,50 \%$ dan pada kondisi $\mathrm{pH} 8$ berkisar antara 13,17\% sampai 18,25\%. Kadar zat penyamak terikat merupakan bagian komponen yang tersisa dari pengurangan komponen air, minyak, zat larut dalam air, abu tak larut dan zat kulit mentah yang terdapat dalam kulit hasil samak. Menurut Kasim (2011), kadar zat penyamak terikat dipengaruhi oleh sifat dan kandungan zat penyamak yang digunakan. Peningkatan kadar zat penyamak terikat disebabkan oleh zat penyamak yang berpenetrasi ke dalam kulit. Menurut Ibrahim et al. (2005), konsentrasi zat penyamak yang lebih tinggi akan menyebabkan reaksi ikatan zat penyamak nabati (gambir) dengan protein kulit akan lebih cepat.

Hubungan antara konsentrasi bahan penyamak gambir yang digunakan pada proses penyamakan dengan derajat penyamakan pada larutan gambir $\mathrm{pH} 4$ dan pH 8 dapat dilihat pada Gambar 2.

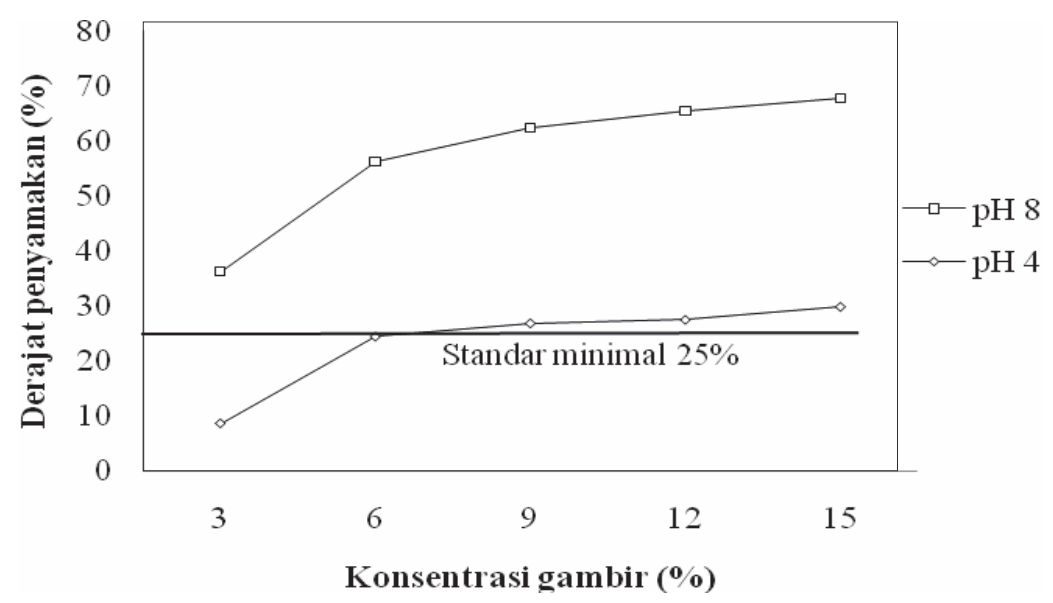

Gambar 2. Hubungan antara konsentrasi bahan penyamak gambir dengan derajat penyamakan pada larutan gambir $\mathrm{pH} 4$ dan $\mathrm{pH} 8$. 
Penggunaan gambir dengan konsentrasi $3 \%$ dan $6 \%$ pada kondisi pH 4 menghasilkan derajat penyamakan kulit tersamak masingmasing yaitu $8,72 \%$ dan $24,45 \%$, hasil ini tidak memenuhi SNI-06-0463-1989-A. Derajat penyamakan paling tinggi adalah $38,01 \%$ yaitu pada penggunaan konsentrasi gambir $15 \%$ dengan kondisi $\mathrm{pH} 8$. Menurut Ibrahim et al. (2005) larutan zat penyamak yang encer akan memiliki molekul zat penyamak yang kecil, daya ikat kecil, penetrasi cepat dan merata. Berdasarkan Gambar 2 terlihat bahwa, derajat penyamakan kulit mengalami peningkatan seiring dengan peningkatan penggunaan konsentrasi gambir, baik pada kondisi $\mathrm{pH} 4$ dan maupun $\mathrm{pH} 8$. Sesuai dengan Akademi Teknologi Kulit (1985) cit Nugraha dan Fahidin (1999) menyatakan, jumlah tanin yang terikat pada kulit dipengaruhi oleh banyaknya tanin yang dapat terdifusi ke dalam jaringan kulit. Oleh sebab itu, semakin tinggi konsentrasi bahan penyamak dapat meningkatkan jumlah tanin terikat dan menurunkan kadar zat kulit mentah kulit samak, sehingga diperoleh derajat penyamakan yang lebih tinggi. Meningkatnya derajat penyamakan didukung oleh data tanin terikat pada setiap perlakuan dimana data tanin terikat perlakuan $\mathrm{pH} 8$ menunjukkan rataan yang lebih tinggi dibandingkan dengan perlakuan penyamakan pada $\mathrm{pH} 4$.

Sesuai Standar Nasional Indonesia (SNI) 06-0994-1989-A, jika derajat penyamakan terlalu tinggi menandakan bahwa kulit masak sempurna serta baik fisiknya, jika derajat penyamakan rendah menandakan kulit belum masak. Jika dibandingkan dengan standar, kulit samak hasil penelitian ini penggunaan gambir pada konsentrasi 3\% dan $6 \%$ pada kondisi pH 4 tidak memenuhi standar, sementara itu pada kondisi $\mathrm{pH} 8$ penggunaan gambir pada berbagai level konsentrasi semuanya memenuhi standar. Batas minimal derajat penyamakan menurut SNI 06-0994-1989-A yaitu 25\% (BSN, 1989).

\section{Sifat fisik kulit kambing tersamak dengan bahan penyamak gambir}

Hasil pengujian sifat fisik kulit kambing yang disamak dengan gambir dapat dilihat pada Tabel 6. Berdasarkan hasil pengukuran kekuatan tarik kulit kambing tersamak dapat dilihat bahwa kekuatan tarik dan kemuluran kulit tersamak dengan menggunakan bahan penyamak gambir pada kondisi $\mathrm{pH} 4$ dan $\mathrm{pH} 8$ menunjukkan peningkatan seiring dengan peningkatan konsentrasi penggunaan gambir. Kekuatan tarik kulit terendah terdapat pada perlakuan penggunaan bahan penyamak gambir 3\% dengan $\mathrm{pH} 4$ dengan kekuatan tarik $356,41 \mathrm{~kg} / \mathrm{cm}^{2}$, sedangkan kekuatan tarik tertinggi berada pada perlakuan dengan penggunaan gambir dengan konsentrasi 15\% dengan nilai $623,00 \mathrm{~kg} / \mathrm{cm}^{2}$ pada $\mathrm{pH} 8$. Begitu juga dengan kemuluran kulit, yang terendah terdapat pada penggunaan gambir $3 \%$ pada kondisi pH 4 yaitu $40,16 \%$ sedangkan kemuluran tertinggi terdapat pada penggunaan gambir pada konsentrasi $15 \%$ pada kondisi $\mathrm{pH} 8$ dengan nilai 52,70\%. Jika dibandingkan dengan SNI-06-0463-1989-A, kekuatan tarik kulit tersamak pada penggunaan berbagai level konsentrasi gambir dengan kondisi $\mathrm{pH}$ larutan gambir

Tabel 6. Sifat fisik kulit tersamak pada penggunaan gambir berbagai konsentrasi dan $\mathrm{pH} 2$.

\begin{tabular}{|c|c|c|c|c|}
\hline \multirow{3}{*}{$\begin{array}{l}\text { Konsentrasi } \\
\text { Gambir }(\%)\end{array}$} & \multicolumn{4}{|c|}{ Sifat fisik kulit tersamak } \\
\hline & \multicolumn{2}{|c|}{ Kekuatan tarik $\left(\mathrm{kg} / \mathrm{cm}^{2}\right)$} & \multicolumn{2}{|c|}{ Kemuluran (\%) } \\
\hline & $\mathrm{pH} 4$ & $\mathrm{pH} 8$ & $\mathrm{pH} 4$ & $\mathrm{pH} 8$ \\
\hline 3 & 356,41 & 427,94 & 40,16 & 45,87 \\
\hline 6 & 403,71 & 498,05 & 47,38 & 40,06 \\
\hline 9 & 403,71 & 538,04 & 54,80 & 42,76 \\
\hline 12 & 440,94 & 568,04 & 42,81 & 43,51 \\
\hline 15 & 450,10 & 623,00 & 49,35 & 52,70 \\
\hline SNI-06-0463-1989-A & \multicolumn{2}{|c|}{ Minimal $75 \mathrm{~kg} / \mathrm{cm}^{2}$} & \multicolumn{2}{|c|}{ Tidak dipersyaratkan } \\
\hline
\end{tabular}




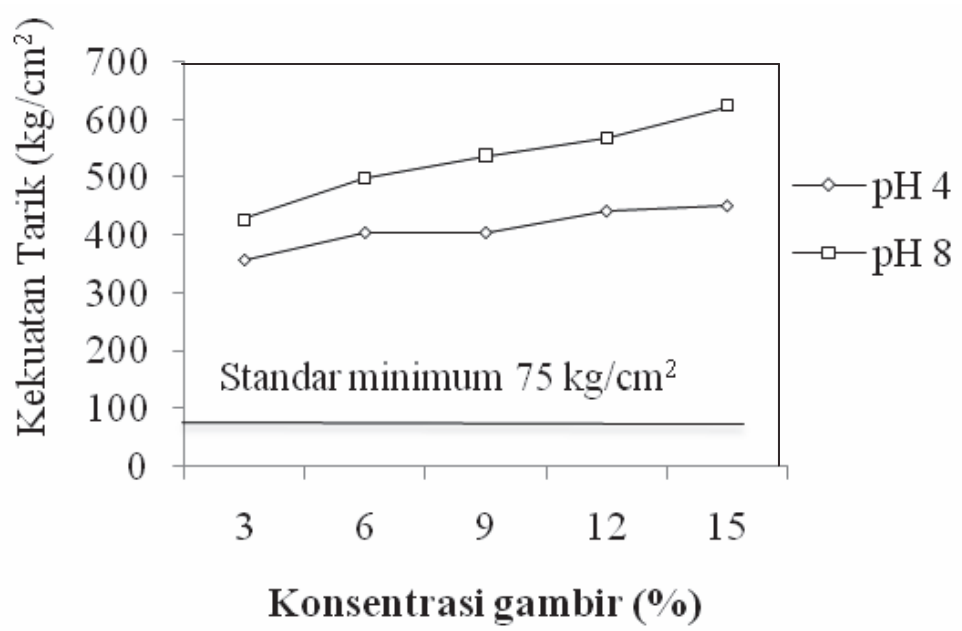

Gambar 3. Hubungan antara konsentrasi bahan penyamak gambir dengan kekuatan tarik kulit tersamak pada penggunaan larutan gambir $\mathrm{pH} 4$ dan $\mathrm{pH} 8$

yang berbeda menunjukkan hasil yang memenuhi standar. Hubungan antara pengaruh berbagai konsentrasi bahan penyamak gambir pada $\mathrm{pH} 4$ dan $\mathrm{pH} 8$ terhadap kekuatan tarik kulit tersamak ditampilkan pada Gambar 3 .

Suramto et al. (1993) menyatakan kekuatan tarik produk kulit tersamak dapat dipengaruhi oleh beberapa faktor diantaranya: ketebalan kulit, struktur kulit dan juga penanganan setelah pengulitan. Selain itu, bahan penyamak dan komposisi dari bahan penyamak tersebut juga sangat menentukan terhadap kualitas kulit termasuk kekuatan tariknya. Ditambahkan oleh Purnomo (1991) faktor lain yang mempengaruhi kuat tarik kulit adalah ketebalan. Semakin tebal kulit maka akan semakin besar pula kuat tariknya (dalam keadaan perlakuan yang sama). Ketebalan akan mempengaruhi kestabilan kulit, dimana kestabilan kulit ini dipengaruhi oleh ikatan silang yang terbentuk antara bahan penyamak dengan protein kulit. Kulit yang telah masak akan mempunyai jumlah ikatan silang yang lebih banyak dari pada kulit yang belum masak, sehingga lebih mampu dan tahan terhadap adanya gaya fisik yang menyerangnya, termasuk air yang mendidih. Begitu juga halnya dengan kemuluran kulit tersamak.

Kemuluran dipengaruhi oleh komposisi protein serat didalam kulit atau kondisi awal kulit sehingga bahan penyamak tidak mempengaruhi data rataan kemuluran kulit serta proses bating. Ibrahim, et al. (2005) menyatakan jika serabut-serabut protein kulit tegak dan rapat, kulit akan mempunyai daya kemuluran yang rendah, tetapi jika serabutserabut kulit letaknya vertikal dan anyaman tidak rapat maka kemuluran akan tinggi. Hubungan antara pengaruh berbagai konsentrasi bahan penyamak gambir terhadap kemuluran kulit kambing tersamak dapat dilihat pada Gambar 4.

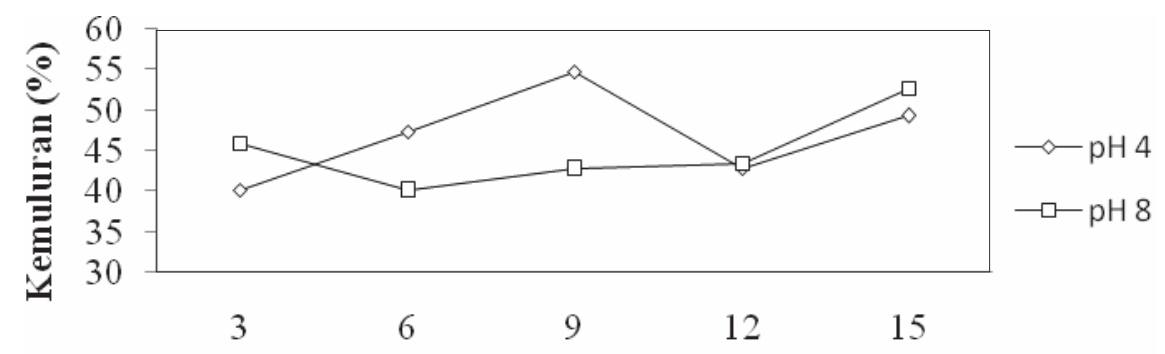

Konsentrasi gambir (\%)

Gambar 4. Hubungan antara konsentrasi bahan penyamak gambir dengan kemuluran pada larutan gambir $\mathrm{pH} 4$ dan $\mathrm{pH} 8$ 


\section{KESIMPULAN}

Kulit kambing Ettawa Sumatera Barat mempunyai luas rata-rata $6945,62 \mathrm{~cm}^{2}$ dengan panjang $101,88 \mathrm{~cm}$, lebar $81,51 \mathrm{~cm}$ dan berat rata-rata satu lembar kulit adalah 1005,16 g. Kulit demikian termasuk kualitas kelas I. Komposisi kimianya adalah: protein 46,89\%, lemak $0,37 \%$, abu $2,17 \%$, zat larut air $0,24 \%$ dan kadar air 27,32\%.

Terjadi perubahan berat selama kulit diolah menjadi pikel dan kemudian diolah menjadi kulit tersamak. Berat pikel bertambah dari berat kulit kering mentah setinggi $84,96 \%$. Rendemen kulit yang dihitung terhadap berat kulit mentah berkisar antara $38,50 \%$ sampai $43,51 \%$ dengan densitas antara 0,63 sampai $0,80 \mathrm{~g} / \mathrm{cm}^{3}$.

Konsentrasi penggunaan gambir yang optimum untuk penyamakan kulit kambing Ettawa adalah 9\% jika larutan gambir $\mathrm{pH} 4$. Sifat kulit pada kondisi optimum diatas seperti berikut: kadar air 18,02\%, kadar minyak $1,15 \%$, kadar zat larut air 19,82\%, kadar zat kulit mentah 50,14\%, kadar tanin terikat $13,47 \%$, derajat penyamakan $26,86 \%$, kekuatan tarik $418,48 \mathrm{~kg} / \mathrm{cm}^{2}$ dan kemuluran pada waktu putus $54,80 \%$.

Konsentrasi penggunaan gambir yang optimum untuk penyamakan kulit kambing Ettawa adalah 3\% jika larutan gambir $\mathrm{pH} 8$. Sifat kulit pada kondisi optimum diatas seperti berikut: kadar air 12,50\%, kadar minyak $2,17 \%$, kadar zat larut air 13,27\%, kadar zat kulit mentah 50,91\%, kadar tanin terikat $13,17 \%$, derajat penyamakan $27,51 \%$, kekuatan tarik 427,94 kg/ $\mathrm{cm}^{2}$ dan kemuluran pada waktu putus $45,87 \%$.

Perlakuan penggunaan gambir pada larutan $\mathrm{pH} 4$, hasil kulit yang memenuhi standar adalah apabila konsentrasi gambir $9 \%$, $12 \%$ dan $15 \%$. Jika larutan gambir pada $\mathrm{pH} 8$, hasil penelitian menunjukkan bahwa semua level konsentrasi yang digunakan memenuhi SNI-06-0463-1989-A yaitu: konsentrasi 3\%, $6 \%, 9 \%, 12 \%$ dan $15 \%$.

\section{UCAPAN TERIMAKASIH}

Ucapan terima kasih disampaikan kepada Dirjen Pendidikan Tinggi (DIKTI) yang telah membiayai penelitian ini melalui skim Hibah Kompetensi dengan kontrak
No. 118/SP2H/PL/Dit.Litabmas/III/2012 dan kepada Balai Besar Kulit Karet dan Plastik (BBKKP) Yogyakarta yang telah membantu dalam pengujian sampel kulit.

\section{DAFTAR PUSTAKA}

Achmad, A., Kassim, J., Suan, T. K., Amat, R. C. and Seey, T. L., 2012. Equilibrium, kinetic and thermodynamic studies on the adsorption of direct dye onto a novel green adsorbent developed from Uncaria gambir extract, Journal of Physical Science, 23(1): 1-13.

BBKKP (Balai Besar Kulit, Karet dan Plastik), 2011. Metode penyamakan kulit. Balai Besar Kulit, Karet dan Plastik, Yogyakarta.

BPS (Badan Pusat Statistik) Provinsi Sumatera Barat, 2009. Pemerintah Provinsi Sumatera Barat, Badan Perencanaan Pembangunan Daerah, Pemerintah Provinsi Sumatera Barat.

BSN (Badan Standardisasi Nasional), 1989. SNI 06-0463-1989-A Kulit lapis domba/kambing samak kombinasi (krom dan nabati).

Brown, E. B. and Shelly, D. C., 2011. Molecular modeling approach to vegetable tanning: preliminary results for gallotannin interactions with the collagen microfibril, JALCA, 106: 113120.

Direktorat Jenderal Peternakan, 2011. Populasi ternak kambing di Provinsi Sumbar, Dinas Peternakan Sumatera Barat, Padang.

Haron, M. A., Khirstova, P., Gasmelseed, G. A. and Covington. A., 2012. Potential of vegetable tanning materials and basic aluminium sulphate in Sudanese leather industry (part II), Suranaree Journal of Science and Technology, 19(1): 31-41.

Ibrahim, L., Juliyarsi, I. dan Melya, S., 2005. Ilmu dan teknologi pengolahan kulit, Fakultas Peternakan Universitas Andalas, Padang.

Kasim, A., 2011. Proses produksi dan industri hilir gambir, Universitas Andalas Press., Padang.

Markmann, D. C., 2009. Vegetable tannin based additives of wood board Industry, Christian D. Markmann GmbH, 
Hamburg.

Nasr, A. I., Abdelsalam, M. M. and Azzam, A. H., 2013. Effect of tanning method and region on physical and chemical properties of barki sheep leather. Journal of Sheep and Goat Sciences, 8(1): 123-130.

Nugraha, G. dan Fahidin, 1999. Pemanfaatan tanin dari kulit kayu akasian sebagai bahan penyamak nabati, Fakultas Teknologi Pertanian IPB, Bogor.

Purnomo, E. dan Wazah, 1984. Teknologi penyamakan kulit 2, Akademi Teknologi Kulit, Yogyakarta.

Purnomo. E., 1991. Penyamakan kulit reptil, Akademi Teknologi Kulit, Yogyakarta.

Roigl, M., Segarra, V., Bertazzo, M., Martinez, M. A., Ferrer, J. and Raspi, C., 2012. Chrome-free leather, tanned with oxazolidine, Journal of AQEIC, 63(4): 101-109.
Suardana, I., Sudiyadnyana, M. dan Rubiyanto, 2008. Kriya kulit jilid I. Direktorat Pembinaan Sekolah Menengah Kejuruan, Jakarta.

Suparno, O., Covinton, A. D. dan Evans, C. S., 2010. Teknologi baru penyamakan kulit ramah lingkungan penyamakan kombinasi menggunakan penyamak nabati, nafto dan oksazolidin, Jurnal Teknologi Industri Pertanian, 18(2): 7984.

Suramto, Pertiwi dan Widhiarti, 1993. Pengaruh lama pengawetan dengan garam terhadap kekuatan tarik dan kemuluran kulit kaki ayam samak krom, Laporan Penelitian, Balai Besar Kulit, Karet dan Plastik, Yogyakarta.

UPTD (Unit Pelaksanaan Teknis Daerah) Padang Panjang, 2011. Prosedur penyamakan kulit, UPTD Padang Panjang, Padang. 
